\title{
Staleya guttiformis gen. nov., sp. nov. and Sulfitobacter brevis sp. nov., $\alpha$-3-Proteobacteria from hypersaline, heliothermal and meromictic antarctic Ekho Lake
}

\author{
Matthias Labrenz, ${ }^{1}$ B. J. Tindall, ${ }^{2}$ Paul A. Lawson, ${ }^{3}$ Matthew D. Collins, ${ }^{3}$ \\ Peter Schumann ${ }^{4}$ and Peter Hirsch ${ }^{1}$
}

\begin{abstract}
Author for correspondence: Peter Hirsch. Tel: +49431 880 4340. Fax: +49 4318802194 e-mail: phirsch@ifam.uni-kiel.de
\end{abstract}

1 Institut für Allgemeine Mikrobiologie, Universität Kiel, D-24118 Kiel, Germany

2 DSMZ - Deutsche Sammlung von Mikroorganismen und Zellkulturen $\mathrm{GmbH}$, D-38124 Braunschweig, Germany

3 Department of Food Science and Technology, University of Reading, Reading RG6 6AP, UK

4 DSMZ - Deutsche Sammlung von Mikroorganismen und Zellkulturen $\mathrm{GmbH}$, D-07745 Jena, Germany

\begin{abstract}
Two Gram-negative, aerobic, pointed and budding bacteria were isolated from various depths of hypersaline, heliothermal and meromictic Ekho Lake (Vestfold Hills, East Antarctica). 16S rRNA gene sequence comparisons show the isolates to be phylogenetically close to the genera Sulfitobacter and Roseobacter. Cells can be motile and contain storage granules. Sulfite addition does not stimulate growth. Isolate EL-38 ${ }^{\mathrm{T}}$ can produce bacteriochlorophyll a and has a weak requirement for sodium ions; polar lipids include phosphatidylglycerol, phosphatidylcholine, phosphatidylethanolamine and an unidentified amino lipid, but not diphosphatidylgycerol. The dominant fatty acid is 18:1 $\omega 7 \mathrm{c}$; other characteristic fatty acids are 3-OH 10:0, 3-OH 14:1, 16:0, 18:0, 18:2 and 19:1. The DNA base composition is $55 \cdot 0-56 \cdot 3 \mathrm{~mol} \% \mathrm{G}+\mathrm{C}$. Isolate EL-162 ${ }^{\top}$ has an absolute requirement for sodium ions. Diphosphatidylglycerol, phosphatidylglycerol, phosphatidylcholine, phosphatidylethanolamine and an unidentified amino lipid are present in the polar lipids. Dominant fatty acids

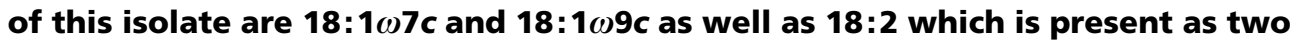
isomers. Other characteristic fatty acids are 3-OH 10:0, 3-OH 14:1, 16:0 and 18:0. The $G+C$ content is $57 \cdot 9-58 \cdot 1 \mathrm{~mol} \%$. Morphological, physiological and genotypic differences from related, thus far known genera support the description of Staleya guttiformis gen. nov. and sp. nov. with EL-38 ( = DSM $11458^{\top}$ ) as the type strain and of Sulfitobacter brevis sp. nov. with the type strain EL-162 ${ }^{\top}$ (= DSM $11443^{\top}$ ).
\end{abstract}

Keywords: Staleya guttiformis gen. nov., sp. nov., Sulfitobacter brevis sp. nov., Antarctica, $\alpha$-Proteobacteria, bacteriochlorophyll $a$

\section{INTRODUCTION}

In the hypersaline Ekho Lake of East Antarctica (Vestfold Hills) salinity increases stepwise with depth, thus forming interface layers. Solar radiation penetrates these and is reflected from below the interfaces, thus resulting 'heliothermally' in locally higher temperatures. The lake has been described as being meromictic with the two lower water bodies

Abbreviations: ASW, artificial seawater; bchl, bacteriochlorophyll. The EMBL accession number for the 16S rRNA sequences are Y16427 (EL-38 ${ }^{\top}$ ) and Y16425 (EL-162'). stable throughout the year (Burton, 1981). Ekho Lake microbiology has been studied only recently, although the changing physical and chemical conditions at different depths offer quite a variety of microhabitats for micro-organisms. The ecology of bacterial isolates from other antarctic hypersaline lakes has been studied in Ekho Lake by James (1996). P. Hirsch, J. Siebert and H. R. Burton investigated the morphological diversity and bacterial numbers of this lake and isolated some 250 bacterial cultures from this source (unpublished). Among these were Antarctobacter heliothermus and Roseovarius tolerans, two new genera and species described by Labrenz et al. (1998, 1999). In the present paper we characterize and describe two additional new bacterial isolates from this lake. 


\section{METHODS}

Water sampling, enrichment conditions and isolations. The procedure of collecting water aseptically from specific depths and the sample treatment were described (Labrenz et al., 1998). For the isolation of $\mathrm{EL}-38^{\mathrm{T}}$, PYGV agar plates (Staley, 1968) were prepared with Ekho Lake water (salinity $15 \%$ ), inoculated with a $1 \mathrm{~m}$ water sample taken on 20 January 1990 and incubated at $15^{\circ} \mathrm{C}$ under dim light $\left(4 \cdot 1 \mu \mathrm{mol}\right.$ photons $\left.\mathrm{m}^{-2} \mathrm{~s}^{-1}\right)$. For the enrichment of strain EL$162^{\mathrm{T}}, 50 \mathrm{ml}$ Ekho Lake water from $8 \mathrm{~m}$ depth was amended with a filter-sterilized solution of $12.5 \mathrm{mg}$ Oxoid yeast extract and incubated as described above.

Bacterial strains. The following strains were used for comparisons: Roseobacter denitrificans (DSM 7001 ${ }^{\mathrm{T}}$ ), Roseobacter litoralis (DSM 6996 ${ }^{\mathrm{T}}$ ) and Sulfitobacter pontiacus (DSM 10014 ${ }^{\mathrm{T}}$ ).

Media and culture conditions. Medium PYGV contained $0 \cdot 25 \mathrm{~g} \mathrm{l}^{-1}$ each of Bacto peptone, Bacto yeast extract and glucose as well as $20 \mathrm{ml} \mathrm{l}^{-1}$ of Hutner's Basal Mineral Salt Solution (HBM; Cohen-Bazire et al., 1957) and $10 \mathrm{ml} \mathrm{1}^{-1}$ of Vitamin Solution no. 6 (van Ert \& Staley, 1971). Media were solidified with $1 \cdot 8 \%$ (w/v) of Bacteriological agar (Gibco). Where needed, liquid and solid media were prepared with $25 \%$ (v/v) of artificial seawater (ASW; Lyman \& Fleming, 1940). R2A Agar (Difco) + ASW was employed for BIOLOG tests. Bacteria for identification tests were incubated at $20^{\circ} \mathrm{C}$. Anaerobic cultivation in the light (4-21.5 $\mu \mathrm{mol}$ photons $\mathrm{m}^{-2} \mathrm{~s}^{-1}$ ) occurred at $16^{\circ} \mathrm{C}$. Biomass for chemotaxonomic studies was grown aerated in liquid $\mathrm{PYGV}+\mathrm{ASW}$ at $20^{\circ} \mathrm{C}$ and harvested in the late exponential phase after $4-8 \mathrm{~d}$.

Microscopy. Cellular morphology of exponential phase broth cultures was examined by phase-contrast light microscopy and by transmission electron microscopy as previously described (Labrenz et al., 1998). For ultrathin sectioning, young cells were prepared as described previously (Labrenz et al., 1999).

Physiological and biochemical characterization. All physiological tests were performed at $20^{\circ} \mathrm{C}$. Gram-staining was carried out on $24 \mathrm{~h}$ cultures (Skerman, 1967). Catalase production was detected with $5 \% \mathrm{H}_{2} \mathrm{O}_{2}$. Peroxidase and cytochrome oxidase activities were tested according to Drews (1974) and Kreisel \& Schauer (1987). DNA hydrolysis was indicated by clear zones around colonies on Bacto DNase Test Agar (Difco) + ASW. Amylase activity and the relation to oxygen were studied according to Smibert \& Krieg (1994). Motility was examined in hanging drop preparations. The ability to grow under various physical and chemical conditions was investigated in liquid media. Osmo-, $\mathrm{NaCl}$-, temperature- and $\mathrm{pH}$-tolerance were studied as by Labrenz et al. (1998, 1999) and evaluated by protein determination (Bradford, 1976) of triplicate cultures. The requirement(s) for vitamins were tested in six combinations, with each lacking one component of Vitamin Solution no. 6: biotin, thiamin. $\mathrm{HCl}$, nicotinic acid, sodium pantothenate or vitamin $\mathrm{B}_{12}$. In these experiments Casein Hydrolysate (vitamin-free; Merck) was used instead of Bacto peptone and Bacto yeast extract. Triplicate results were recorded after three serial transfers in the corresponding test media. Requirements for $\mathrm{Na}^{+}, \mathrm{K}^{+}, \mathrm{Mg}^{2+}, \mathrm{Ca}^{2+}, \mathrm{Cl}^{-}$or $\mathrm{SO}_{4}^{2-}$ were studied in $\mathrm{PYGV}+\mathrm{ASW}$ where $\mathrm{Na}^{+}$was exchanged with $\mathrm{K}^{+}$, $\mathrm{Mg}^{2+}$ with $\mathrm{Ca}^{2+}, \mathrm{Cl}^{-}$with $\mathrm{SO}_{4}^{2-}$ and vice versa. Susceptibility to antibiotics was determined after four days with bioDiscs (bioMérieux). Aerobic nitrate reduction was tested after
Table 1. Solid media for testing growth of the Ekho Lake strains and S. pontiacus DSM $10014^{\top}$ on increasing initial sulfite concentrations $\left(I^{-1}\right)$

All media contained $\left(1^{-1}\right) 20 \mathrm{ml}$ Hutner's basal medium, $10 \mathrm{ml}$ vitamin solution no. $6,0 \cdot 25 \mathrm{~g}$ yeast extract, $15 \mathrm{~g} \mathrm{NaCl}$ and $3 \mathrm{ml}$ bromothymol blue ( $1 \%)$.

\begin{tabular}{|c|c|c|c|c|}
\hline \multirow[t]{2}{*}{ Substance } & \multicolumn{4}{|c|}{ Medium } \\
\hline & 1 & 2 & 3 & 4 \\
\hline Na-acetate & $15 \mathrm{mM}$ & $10 \mathrm{mM}$ & $5 \mathrm{mM}$ & $5 \mathrm{mM}$ \\
\hline Na-sulfite & $7.5 \mathrm{mM}$ & $15 \mathrm{mM}$ & $45 \mathrm{mM}$ & $60 \mathrm{mM}$ \\
\hline HEPES & $8 \cdot 0 \mathrm{~g}$ & $1 \cdot 0 \mathrm{~g}$ & - & - \\
\hline Bacto peptone & $0 \cdot 25 \mathrm{~g}$ & $0 \cdot 25 \mathrm{~g}$ & $0 \cdot 10 \mathrm{~g}$ & $0 \cdot 10 \mathrm{~g}$ \\
\hline Bacteriological agar & $18 \mathrm{~g}$ & $18 \mathrm{~g}$ & $18 \mathrm{~g}$ & $20 \mathrm{~g}$ \\
\hline
\end{tabular}

$14 \mathrm{~d}$, anaerobic reduction to nitrite or $\mathrm{N}_{2}$ after three weeks incubation. In both cases PYGV + ASW was employed with $5 \mathrm{mM} \mathrm{NaNO}$. Anaerobic photolithoautotrophic or photoorganotrophic growth was examined in PYGV + ASW as described by Labrenz et al. (1998, 1999). Production of poly$\beta$-hydroxybutyrate was followed in medium PHBA + ASW, which was PYGV modified to contain $20 \mathrm{ml} \mathrm{HBM} \mathrm{l}^{-1}, 10 \mathrm{ml}$ Vitamin Solution no. 6, 0.1 g Bacto yeast extract and $2 \cdot 0 \mathrm{~g}$ succinate according to Smibert \& Krieg (1994). Methyl red and Voges-Proskauer tests were performed in PYGV+ ASW with $0 \cdot 2 \%(\mathrm{w} / \mathrm{v})$ Bacto peptone and $0.2 \%(\mathrm{w} / \mathrm{v})$ glucose. $\mathrm{H}_{2} \mathrm{~S}$ and indole productions were tested with the Sulfide Indole Motility medium (Merck) + ASW. Indole was detected with Kóvacs reagent.

The aerobic dissimilation of 95 carbon sources with the BIOLOG System and carbon source utilization in a minimal medium were studied as described by Labrenz et al. (1998, 1999). Degradation of the following substrates was tested with the basal medium PYV + ASW, i.e. lacking glucose and containing $(\mathrm{w} / \mathrm{v}): 0 \cdot 2 \%$ starch, $0.4 \%$ gelatin, $1 \%$ Tween 80 or $0.75 \%$ alginate. Production of bchl $a$ was followed in suspensions of cells grown in PYGV + ASW and analysed as described (Shiba \& Simidu, 1982). Tests were performed with cells grown in constant light at $4-21.5 \mu$ mol photons $\mathrm{m}^{-2} \mathrm{~s}^{-1}$ or with dark-grown cells.

Growth with sulfite. The Ekho Lake strains and S. pontiacus DSM $10014^{\mathrm{T}}$ were adapted to increasing sulfite concentrations on previously described, but modified media (Sorokin \& Lysenko, 1993; Sorokin, 1995; Table 1). Adaptation started with solid sulfite medium 1 and ended on solid medium 4. Cultivation occurred for 8-16 d. In order to obtain high initial sulfite concentrations, the media were inoculated immediately after autoclaving. Growth was controlled on media without Na-sulfite. Growth was also determined in liquid medium. For this, sulfite-adapted cells were taken from solid medium 3 and inoculated into modified liquid medium 3 containing $0,10,20,45$ or $60 \mathrm{mM}$ Na-sulfite; an indicator was not added. After $9 \mathrm{~d}$ incubation at $20{ }^{\circ} \mathrm{C}$, protein contents were determined.

Chemotaxonomy. Analysis of fatty acid methyl esters (FAMEs) was performed with $20 \mathrm{mg}$ freeze-dried biomass as previously described (Labrenz et al., 1998). FAMEs 
which could not be identified on the basis of their retention times were analysed by GC-MS using a model GCMSQP2000 instrument (Shimadzu) under gas chromatographic conditions as described previously (Groth et al., 1996). Respiratory lipoquinones and polar lipids were extracted from $100 \mathrm{mg}$ freeze-dried material using a two-stage method and analysed as described before (Tindall, 1990a, b). Bacteriochlorophyll was detected initially in the lipid extracts, and was visible as a green band on the TLC plates. Diamino acids of cell walls were separated by one-dimensional TLC on cellulose using the solvent system of Rhuland et al. (1955).

Determination of DNA base composition. DNA $\mathrm{G}+\mathrm{C}$ contents (mol \%) were analysed using HPLC (Mesbah et al., 1989). The HPLC apparatus (Pharmacia-LKB) was equipped with a Spherisorb ODS II $\mathrm{C}_{18}$ column $(5 \mu \mathrm{m}$; $4 \times 250 \mathrm{~mm}$; Bischoff). Escherichia coli strain B type VIIIDNA (Sigma) and $\lambda$ phage DNA from $E$. coli host strain GM 119 (Sigma) were used as standards.

DNA-DNA hybridization. Dot-blot hybridization experiments were carried out with the DIG DNA Labelling and Detection kit from Boehringer Mannheim following manufacturer's instructions. DNA probes were prepared from EL-38 ${ }^{\mathrm{T}}$, EL-162 ${ }^{\mathrm{T}}$ and Sulfitobacter pontiacus ${ }^{\mathrm{T}}$. Hybridization occurred against chromosomal DNA from Ekho Lake isolates and the type strains of Sulfitobacter pontiacus and Roseobacter denitrificans. The stringency of $70 \%$ was calculated according to Sambrook et al. (1989).

16S rRNA gene sequence determination and analysis of sequence data. $16 \mathrm{~S}$ rRNA gene fragments were generated by PCR as described by Hudson et al. (1993). A large fragment of the 16S rRNA gene was amplified from DNA by PCR using universal primers pA (positions 8-28, E. coli numbering) and $\mathrm{pH}^{*}$ (1542-1522). The amplified product was purified by using a QIAquick PCR Purification kit (Qiagen) and sequenced directly using primers to conserved regions of the rRNA. Sequencing was performed using a PRISM Taq DyeDeoxy Terminator Cycle Sequencing kit (Applied Biosystems) and an automatic DNA sequencer (model 373A, Applied Biosystems). To establish the closest relatives of the Ekho Lake strains, preliminary searches in the EMBL database were performed with the program FASTA (Pearson \& Lipman, 1988). Sequences closely related to those of the Ekho Lake strains were retrieved from the EMBL database and aligned with the newly determined sequences using the program PILEUP (Devereux et al., 1984). The rRNA alignment was corrected manually and approximately 100 bases at the $5^{\prime}$ end of the molecule were omitted from further analysis because of alignment uncertainties due to the highly variable region V1. Percentage sequence similarities were calculated and corrected for substitution rates by using Jukes \& Cantor (1969) parameters. A phylogenetic tree was constructed according to the neighbour-joining method (Saitou \& Nei, 1987) with the program NEIGHBOR. For this analysis, the following additional taxa, listed by genera and accession number, were included: Rhodovulum euryhalinum (D13479), Rhodovulum sulfidophilum (U55277), Rhodovulum adriaticum (D16418), Rhodobacter blasticus (D16429), Rhodobacter capsulatus (D16428), Rhodobacter sphaeroides (D16425), Rhodobacter veldkampii (D16421), Paracoccus denitrificans (X69159) and Paracoccus kocurii (D32241). The stability of the groupings was estimated by bootstrap analysis (500 replications) using the programs of the PHYLIP package (Felsenstein, 1989).

\section{RESULTS}

\section{Isolations}

EL-38 ${ }^{\mathrm{T}}$ was isolated from a $1 \mathrm{~m}$ Ekho Lake water sample, which had a salinity of $10 \%$, a temperature of $5^{\circ} \mathrm{C}$, and a pH of 8.09 . EL- $162^{\mathrm{T}}$ came from an $8 \mathrm{~m}$ water sample with a salinity of $55 \%$, a temperature of $11.5^{\circ} \mathrm{C}$ and a $\mathrm{pH}$ of 8.3 . The pure cultures were kept on PYGV slants with the appropriate concentration of ASW, corresponding to that of the original sample.

\section{Morphology and motility}

Both isolates were Gram-negative short rods with one or both cell poles narrower (Fig. 1). Cells of EL-38 ${ }^{\mathrm{T}}$ were more pointed (Fig. 1a, c) and those of EL-162 often more coccoid (Fig. 1b, d). The isolates frequently formed rosettes (Table 2) and often contained poly$\beta$-hydroxybutyrate granules. Motility was observed in both strains and electron microscopy revealed a flagellum in strain EL-38 ${ }^{\mathrm{T}}$, but the point of insertion could not be determined. Flagella were not detected in strain EL-162 ${ }^{\mathrm{T}}$.

\section{Culture and growth characteristics}

Aerobic growth of both strains was visible after 3-5 d on PYGV $+25 \%$ ASW and at $20{ }^{\circ} \mathrm{C}$. Colonies were in both cases circular, smooth, convex, beige or yellowish-brown and had a diameter of $1-3 \mathrm{~mm}$ (Table 2). Older colonies of EL-38 ${ }^{\mathrm{T}}$ changed from beige to pink.

Strain EL- $38^{\mathrm{T}}$ grew between $<4$ and $<32{ }^{\circ} \mathrm{C}$ and at $\mathrm{pH}$ values of 5.5 to $>9 \cdot 5$. Optimal growth occurred at $\mathrm{pH}$ values of $7 \cdot 0-8 \cdot 5$. Its osmotolerance ranged from $<10$ to $130-150 \%$ ASW, with an optimum between 10 and $40 \%$. NaCl was found to be tolerated from $<1.0$ to $2.5-4.0 \%$, with an optimum of $1.0 \% \mathrm{NaCl}$. The temperature range for growth of EL-162 ${ }^{\mathrm{T}}$ was between $<3$ and $33.5^{\circ} \mathrm{C}$, and growth occurred between $\mathrm{pH}$ values of 5.5 and 9.5 , with an optimum between 7.5 and $8 \cdot 0$. The osmotolerance of EL-162 ranged from $<10$ to $>150 \%$ ASW, and was optimal between 10 and $80 \%$. The $\mathrm{NaCl}$ tolerance range was $<1.0$ to $8.0 \%$, with an optimum of $1.0-2.0 \% \mathrm{NaCl}$. Other growth characteristics are shown in Table 2.

EL-38 ${ }^{\mathrm{T}}$ had a weak and EL-162 ${ }^{\mathrm{T}}$ an absolute requirement for $\mathrm{Na}^{+}$; the other cations and anions could all be replaced as indicated in Methods. Both ELisolates had a requirement for pantothenate, a weak requirement for biotin and nicotinic acid, but none for vitamin $B_{12}$. Both strains also required thiamin, but EL- $38^{\mathrm{T}}$ only weakly.

\section{5 rRNA gene sequence determinations and phylogenetic analyses}

The almost complete 16S rRNA gene sequences of strains EL-38 ${ }^{\mathrm{T}}$ and EL-162 ${ }^{\mathrm{T}}$ were determined. Sequence searches of the EMBL database revealed that the newly determined sequences were related to the $\alpha$ - 
Table 2. Differential characteristics of Staleya guttiformis EL-38 ${ }^{\top}$ and Sulfitobacter brevis EL-162 ${ }^{\top}$ with closely related $\alpha$-Proteobacteria

Strains (data from this study, except where reference is given): 1, Staleya guttiformis EL-38 ${ }^{\mathrm{T}} ; 2$, Sulfitobacter brevis EL-162 ${ }^{\mathrm{T}}$; 3 , Sulfitobacter pontiacus DSM 10014 ${ }^{\mathrm{T}}$ (Sorokin, 1995); 4, Roseobacter litoralis DSM 6996 ${ }^{\mathrm{T}}$ (Shiba, 1991); 5, Roseobacter denitrificans DSM 7001 $1^{\mathrm{T}}$ (Shiba, 1991); 6, Octadecabacter antarcticus 307 ${ }^{\mathrm{T}}$ (Gosink et al., 1997); 7, Octadecabacter arcticus 238 ${ }^{\mathrm{T}}$ (Gosink et al., 1997); 8, Marinosulfonomonas methylotropha PSCH4 ${ }^{\mathrm{T}}$ (Holmes et al., 1997); 9, Sagittula stellata ATCC 700073 ${ }^{\mathrm{T}}$ (Gonzalez et al., 1997); 10, Antarctobacter heliothermus DSM 11445' (Labrenz et al., 1998); 11, Roseovarius tolerans DSM $11457^{\mathrm{T}}$ (Labrenz et al., 1999); 12, Ruegeria algicola ATCC 51440 ${ }^{\mathrm{T}}$ (Lafay et al., 1995); 13, Roseobacter gallaeciensis CIP $105210^{\mathrm{T}}$ (Ruiz-Ponte et al., 1998). v, Variable; w, weak; ND, not determined.

\begin{tabular}{|c|c|c|c|c|c|c|c|c|c|c|c|c|c|}
\hline Characteristic & 1 & 2 & 3 & 4 & 5 & 6 & 7 & 8 & 9 & 10 & 11 & 12 & 13 \\
\hline \multicolumn{14}{|l|}{ Morphology: } \\
\hline Rosettes formed & + & + & + & - & - & - & - & + & + & + & - & - & ND \\
\hline Bud formation & + & + & + & - & - & - & - & ND & ND & + & + & - & ND \\
\hline \multicolumn{14}{|l|}{ Physiology: } \\
\hline Oxidase & + & + & + & + & + & - & - & + & + & + & + & + & + \\
\hline $\operatorname{Bchl} a$ & $\mathrm{~V}$ & - & - & + & + & - & - & - & - & - & + & - & - \\
\hline Growth at $37^{\circ} \mathrm{C}$ & - & - & - & - & - & - & - & + & + & + & + & + & + \\
\hline Gelatin hydrolysis & - & - & - & + & + & - & - & ND & - & + & - & + & - \\
\hline C-source: citrate & - & + & - & + & + & - & $\mathrm{V}$ & + & + & + & - & + & - \\
\hline C-source: butyrate & - & + & + & - & - & - & - & ND & + & + & $\mathrm{w}$ & $-*$ & + \\
\hline C-source: methanol & - & - & ND & - & - & - & - & + & + & - & - & - & ND \\
\hline Pantothenate requirement & + & + & ND & - & - & - & + & ND & - & - & - & - & - \\
\hline Fatty acids $(\%)$ & & & $\dagger$ & $\S$ & $\S$ & & & & & & & $\S$ & \\
\hline 3-OH 10:0 & $5 \cdot 9$ & $4 \cdot 5$ & $3 \cdot 6$ & $1 \cdot 9$ & $4 \cdot 2$ & 2 & 4 & ND & - & - & - & - & ND \\
\hline 3-OH 12:1 & - & - & - & - & - & - & - & ND & $3 \cdot 6$ & $3 \cdot 1$ & $3 \cdot 6$ & - & ND \\
\hline 3-OH 14:1 & $2 \cdot 1$ & $2 \cdot 6$ & $2 \cdot 0$ & $3 \cdot 9$ & - & - & - & ND & - & - & - & - & ND \\
\hline $16: 1 \omega 7 c$ & - & - & $1 \cdot 2$ & - & $1 \cdot 4$ & 12 & 8 & ND & - & $0 \cdot 8$ & $0 \cdot 8$ & - & ND \\
\hline $16: 0$ & $3 \cdot 9$ & $5 \cdot 8$ & $8 \cdot 1$ & $1 \cdot 1$ & $1 \cdot 6$ & 6 & 6 & ND & $8 \cdot 6$ & $2 \cdot 5$ & $6 \cdot 2$ & $1 \cdot 6$ & ND \\
\hline $18: 2 \|$ & - & $3 \cdot 2$ & - & - & - & - & - & ND & - & - & - & - & ND \\
\hline $18: 2$ & $5 \cdot 3$ & $7 \cdot 8$ & - & $1 \cdot 4$ & $7 \cdot 1$ & - & - & ND & - & - & $10 \cdot 6$ & $1 \cdot 6$ & ND \\
\hline $18: 1 \omega 9 c$ & - & $18 \cdot 9$ & - & - & - & - & - & ND & - & - & - & - & ND \\
\hline $18: 1 \omega 7 c$ & $79 \cdot 7$ & $50 \cdot 0$ & $79 \cdot 1$ & $88 \cdot 8$ & $84 \cdot 6$ & $77 \#$ & $75 \#$ & ND & $* *$ & $83 \cdot 2$ & $70 \cdot 2$ & $91 \cdot 5$ & ND \\
\hline $18: 0$ & $0 \cdot 7$ & 0.9 & - & $1 \cdot 3$ & $1 \cdot 2$ & - & - & ND & $6 \cdot 8$ & $1 \cdot 0$ & $0 \cdot 8$ & $2 \cdot 2$ & ND \\
\hline cyclo 19:0 & - & - & - & - & - & - & - & ND & $1 \cdot 8$ & $2 \cdot 4$ & - & - & ND \\
\hline $19: 1$ & $1 \cdot 4$ & - & - & - & - & - & - & ND & - & - & - & - & ND \\
\hline Polar lipids: & & & $t$ & $\S$ & $\S$ & & & & & & & $\S$ & \\
\hline Diphosphatidylglycerol & - & + & + & + & + & ND & ND & ND & ND & - & + & + & ND \\
\hline Phosphatidylethanolamine & + & + & + & - & - & $\mathrm{ND}$ & ND & ND & ND & - & + & + & ND \\
\hline Phosphatidylcholine & + & + & + & - & + & ND & ND & ND & ND & + & + & + & ND \\
\hline $\mathrm{G}+\mathrm{C}$ content $(\mathrm{mol} \%)$ & $55-56$ & 58 & $62-63$ & $56-59$ & 60 & 56 & 57 & 57 & 65 & $62-64$ & 63 & $64-65 \S$ & 58 \\
\hline
\end{tabular}

* May also be positive (Labrenz et al., 1999).

$\dagger$ Grown on Marine Broth 2216 (Difco).

t Data from the present study.

$\S$ Data from Labrenz et al. (1999).

$\|$ First isomer, which could not be further identified.

- Second isomer, which could not be further identified.

\# Unclear if $18: 1 \omega 7 c, 18: 1 \omega 9 t$ or $18: 1 \omega 12 t$.

** Major fatty acid, but not quantified.

subclass of the Proteobacteria (data not shown). Both EL-strains displayed highest 16S rRNA gene sequence relatedness (approx. 96.5-98\%) with Sulfitobacter pontiacus (Sorokin, 1995). Also high sequence relatedness was observed with Roseobacter denitrificans and Roseobacter litoralis. Other species belonging to the $\alpha$-subclass of Proteobacteria examined showed lower levels of relatedness. An unrooted tree depicting the phylogenetic relationships of the unknown Ekho Lake bacteria and their closest relatives is shown in Fig. 2. The results of treeing analyses showed that the Ekho Lake strain EL-162 ${ }^{\mathrm{T}}$ phylogenetically clustered 

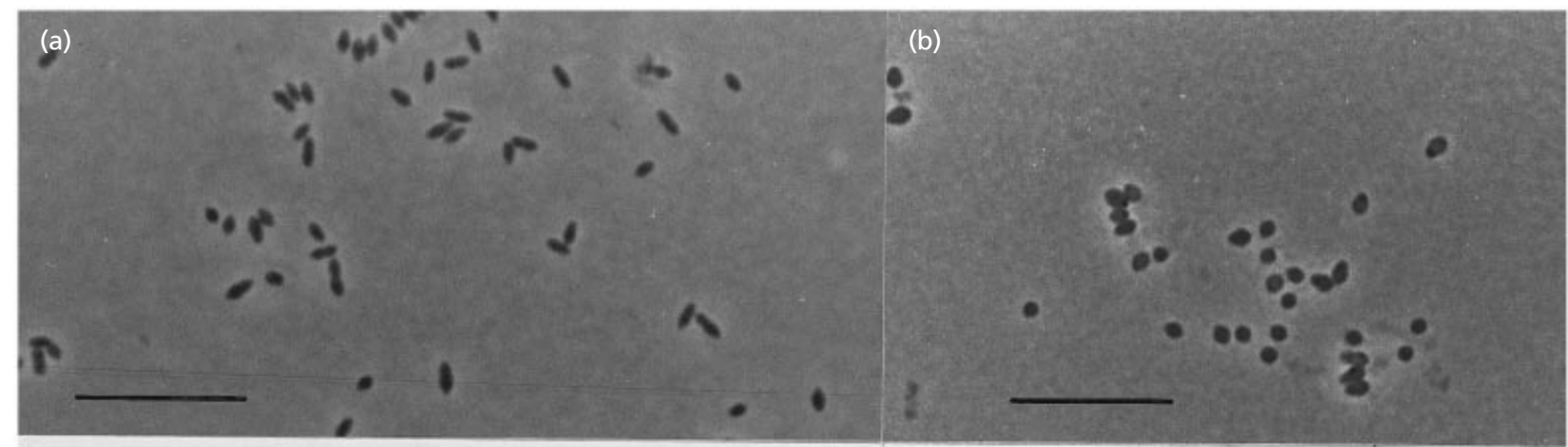

(c)

(d)

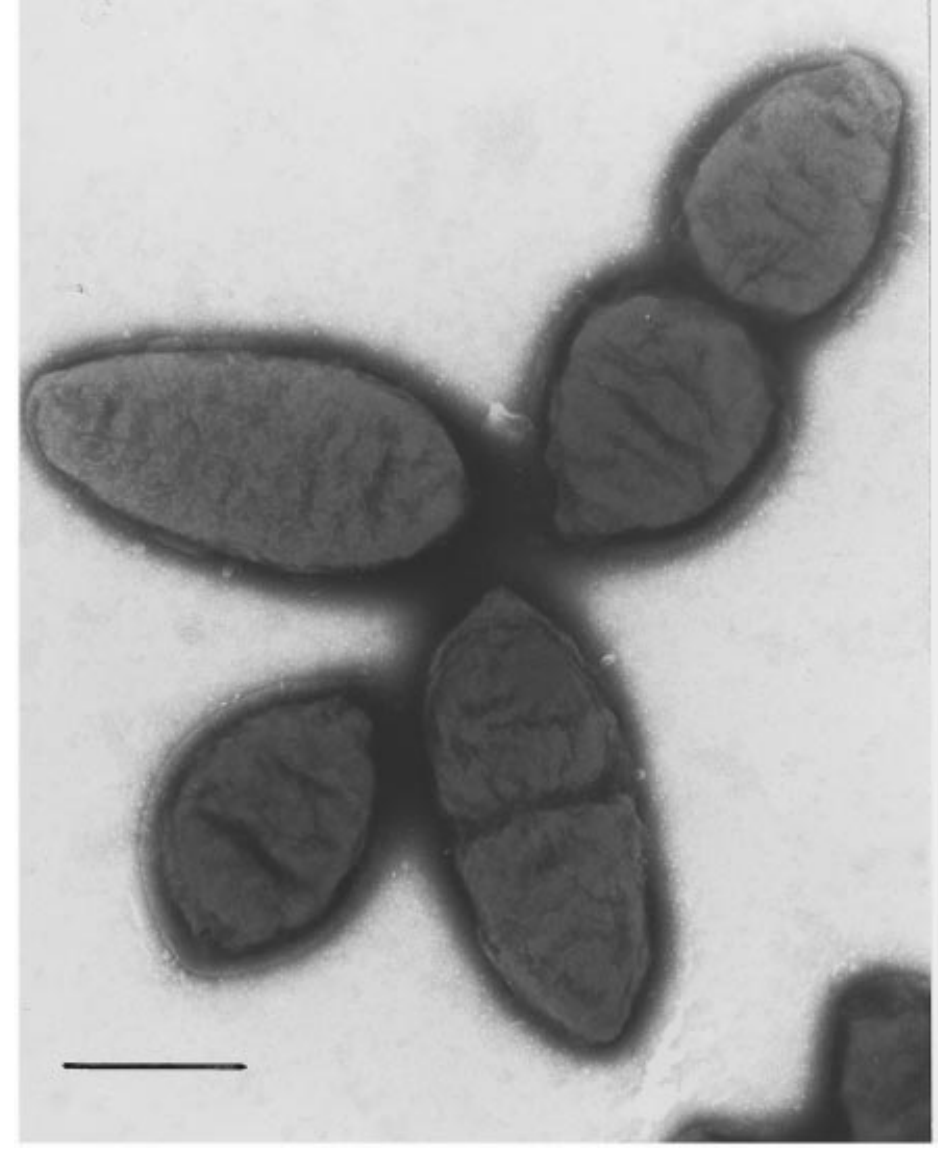

Fig. 1. Phase-contrast light micrograph of Staleya guttiformis EL-38 ${ }^{\top}$ (a) and Sulfitobacter brevis EL-162 ${ }^{\top}$ (b) on an agarcoated slide (Pfennig \& Wagener, 1986). Bars, $15 \mu \mathrm{m}$ (a) and $10 \mu \mathrm{m}$ (b). Electron micrograph of PTA negatively stained cells of strain EL-38 $8^{\top}$ (c) and EL-162 ${ }^{\top}$ (d). Bars, $1 \mu \mathrm{m}$.

with Sulfitobacter pontiacus, while EL- $38^{\mathrm{T}}$ formed a distinct subline.

\section{Chemotaxonomic characteristics}

The peptidogylcan of both isolates contained mesodiaminopimelic acid. The only respiratory lipoquinones detected were ubiquinones, with ubiquinone 10 as the dominant isoprenologue. The presence of ubiquinone 10 as the dominant respiratory lipoquinone is characteristic of members of the $\alpha$-subclass of the Proteobacteria. The predominant fatty acid was $18: 1 \omega 7 c$ (Table 2), accounting for $50-80 \%$ of the total fatty acids, a feature characteristic of several major phyletic groups within the $\alpha$-subclass of the Proteobacteria. The presence of 3-OH 10:0 and a compound provisionally identified as $3-\mathrm{OH} 14: 1$, the latter being exclusively (presumptively) amide bound is indicative of the fact that the novel isolates belonged within the same phyletic group as members of the genera Roseobacter or Ruegeria (Ushino et al., 1998). In previous work the compound presumptively identified here as 3 - 


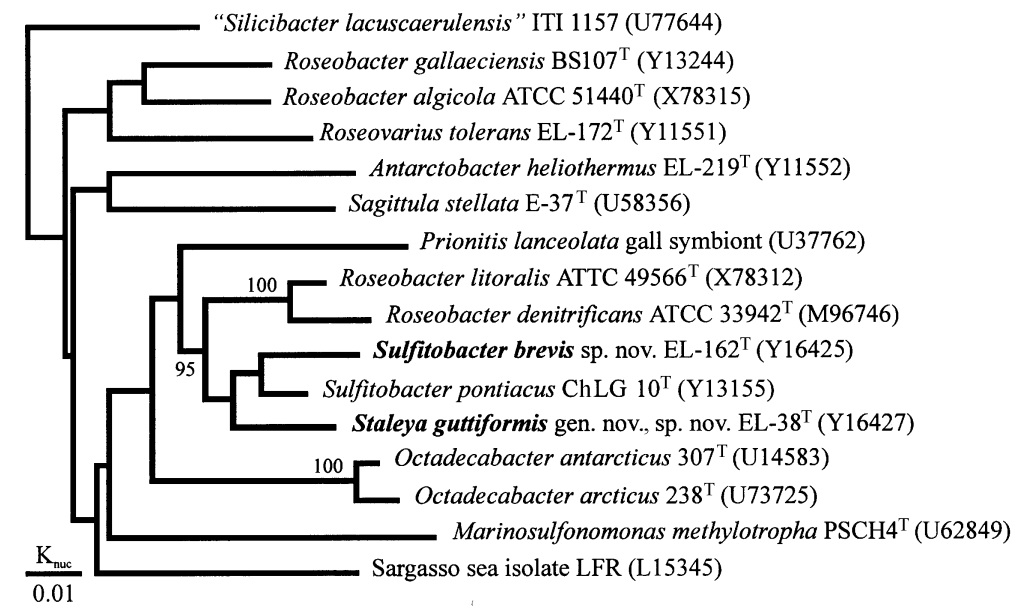

Fig. 2. Unrooted tree showing phylogenetic relationships of Ekho Lake strains with Roseobacter spp., S. pontiacus and closely related Proteobacteria. Additional sequences were used to perform the phylogenetic analyses (see Methods). The tree was constructed using the neighbourjoining method ( $K_{\text {nuc }}$ values). It was based on a comparison of 1320 nucleotides. Bootstrap values, expressed as a percentage of 500 replications, are given at branching points; only those above $90 \%$ are shown.

$\mathrm{OH}$ 14: 1 was incorrectly labelled 2-OH 14:0 (Labrenz et al., 1998, 1999). The polar lipids of the two novel isolates were not identical, with phosphatidylglycerol, phosphatidylethanolamine and phosphatidylcholine, together with an unidentified amino lipid being present in both strains. Strain EL- $38^{\mathrm{T}}$ differed from strain EL$162^{\mathrm{T}}$ in that it did not produce diphosphatidylglycerol. This pattern was similar to that of Sulfitobacter pontiacus, but significantly different from members of the genus Roseobacter, which do not synthesize phosphatidylethanolamine.

\section{Physiological and biochemical characteristics}

Phenotypic and biochemical characteristics which differentiated EL-38 ${ }^{\mathrm{T}}$ and EL-162 ${ }^{\mathrm{T}}$ from possibly related type strains of Sulfitobacter pontiacus, Roseobacter litoralis or Roseobacter denitrificans, are listed in Table 2. In addition, both strains exhibited peroxidase and cytochrome oxidase activity and produced catalase, but EL-38 ${ }^{\mathrm{T}}$ only weakly. They did not produce acetoin or acids from glucose. Neither sulfide nor indole were produced. They were susceptible to chloramphenicol $(30 \mu \mathrm{g})$, streptomycin $(10 \mu \mathrm{g})$, polymyxin $\mathrm{B}(300 \mathrm{U})$, penicillin $\mathrm{G}(10 \mathrm{U})$ or tetracycline $(30 \mu \mathrm{g})$. EL-38 ${ }^{\mathrm{T}}$ was also susceptible to nalidixic acid $(30 \mu \mathrm{g})$, but EL-162 ${ }^{\mathrm{T}}$ was not. The two strains were not able to reduce nitrate anaerobically or nitrite aerobically. Neither of the strains hydrolysed alginate or starch. In the presence of available nitrogen, they utilized succinate, glutamate, acetate, pyruvate or malate, but not methanol or methanesulfonic acid. $\alpha$ D-Glucose was only weakly utilized. In the BIOLOG system, the two EL-strains metabolized acetic acid, itaconic acid, propionic acid, and weakly i-erythritol. They did not metabolize $\alpha$-cyclodextrin, dextrin, glycogen, methylpyruvate, monomethylsuccinate, cis-aconitic acid, formic acid, D-galactonic acid lactone, Dgalacturonic acid, $\alpha$-hydroxybutyric acid, $\beta$-hydroxybutyric acid, $\gamma$-hydroxybutyric acid, $p$-hydroxyphenylacetic acid, $\alpha$-ketobutyric acid, $\alpha$-ketovaleric acid, DLlactic acid, sebacic acid, succinic acid, bromosuccinic acid, succinamic acid, D-alanine, L-alanine, Lasparagine, L-aspartic acid, L-glutamic acid, glycyl-Laspartic acid, glycyl-L-glutamic acid, L-histidine, hydroxy-L-proline, L-leucine, L-ornithine, L-phenylalanine, L-proline, L-pyroglutamic acid, L-threonine, DL-carnitine, $\gamma$-aminobutyric acid, urocanic acid, phenylethylamine, putrescine, 2-aminoethanol, 2,3butanediol or glycerol. Differences in the metabolism of carbon compounds as revealed with the BIOLOG system are shown in Table 3. They did not grow anaerobically and photolithoautotrophically with $\mathrm{H}_{2} / \mathrm{CO}_{2}(80: 20)$ in the gas phase, and they did not grow photo-organotrophically.

Bacteriochlorophyll $a$ was present in dark-grown cell suspensions of EL-38 ${ }^{\mathrm{T}}$, but not in EL-162 ${ }^{\mathrm{T}}$. Characteristic absorbances were found with a larger peak at 861-862 $\mathrm{nm}$ and smaller ones at 800-802 and 590 $592 \mathrm{~nm}$ (Fig. 3). These differed from the maxima of bchl a-containing Roseobacter denitrificans and Roseobacter litoralis (Shiba, 1991) or Roseovarius tolerans (Labrenz et al., 1999). Other features, such as carotenoids, were not characterized further. The bchl $a$ production by EL-38 $8^{\mathrm{T}}$ was very low in constant dim light, with only a very small peak at $865 \mathrm{~nm}$ after 2 weeks. Unlike Roseobacter denitrificans, vesicular structures of intracytoplasmatic membrane systems (Harashima et al., 1982) were never found in ultrathin sections of aerobically and dark grown cells of EL-38 ${ }^{\mathrm{T}}$.

\section{Growth with sulfite}

Unlike Sulfitobacter pontiacus (Sorokin, 1995), the addition of sulfite did not stimulate growth of EL-38 or EL-162 ${ }^{\mathrm{T}}$ in liquid media. The Sulfitobacter pontiacus type strain grew at initial sulfite concentrations of 0 , 10,20 and to a lower degree at 45 or even $60 \mathrm{mM}$. Here the protein content was significantly higher with $10 \mathrm{mM}$ sulfite than in sulfite-free media. EL-162 ${ }^{\mathrm{T}}$ grew at concentrations of $0,10,20$ and to a lesser extent at $45 \mathrm{mM}$, but not at $60 \mathrm{mM}$ sulfite. Growth of EL-38 occurred at 0,10 and less well at $20 \mathrm{mM}$, but not at 45 or $60 \mathrm{mM}$ sulfite. On autoclaved, unbuffered solid 
Table 3. Differences of strains EL- $38^{\top}$ and $E L-162^{\top}$ in the metabolism of carbon compounds as revealed by the BIOLOG system

+ , Positive; -, negative; w, weak.

\begin{tabular}{|c|c|c|}
\hline Substrate & EL-38 ${ }^{\mathrm{T}}$ & EL-162 \\
\hline Tween 40 & + & w \\
\hline Tween 80 & - & + \\
\hline$N$-Acetyl-D-galactosamine & - & + \\
\hline$N$-Acetylglucosamine & - & + \\
\hline Adonitol & - & + \\
\hline L-Arabinose & - & + \\
\hline D-Arabitol & - & + \\
\hline Cellobiose & - & w \\
\hline D-Fructose & w & + \\
\hline L-Fucose & w & + \\
\hline D-Galactose & - & + \\
\hline Gentiobiose & - & + \\
\hline$\alpha$-D-Glucose & $\mathrm{w}$ & + \\
\hline meso-Inositol & - & w \\
\hline$\alpha$-Lactose & W & + \\
\hline D-Glucosaminic acid & - & w \\
\hline$\alpha$-D-Lactose-lactulose & $\mathrm{w}$ & + \\
\hline Maltose & - & + \\
\hline D-Mannitol & - & w \\
\hline D-Mannose & - & + \\
\hline D-Melibiose & $\mathrm{w}$ & + \\
\hline Methyl $\beta$-D-glucoside & - & w \\
\hline Psicose & - & $\mathrm{w}$ \\
\hline D-Raffinose & - & + \\
\hline L-Rhamnose & w & + \\
\hline D-Sorbitol & - & + \\
\hline Sucrose & $\mathrm{w}$ & + \\
\hline D-Trehalose & $\mathrm{w}$ & + \\
\hline Turanose & - & + \\
\hline Xylitol & - & w \\
\hline Citric acid & - & + \\
\hline D-Gluconic acid & - & w \\
\hline D-Glucuronic acid & - & W \\
\hline$\alpha$-Ketoglutaric acid & - & w \\
\hline Malonic acid & - & w \\
\hline Quinic acid & - & $\mathrm{w}$ \\
\hline D-Saccharic acid & - & w \\
\hline Glucuronamide & - & + \\
\hline Alaninamide & - & $\mathrm{w}$ \\
\hline L-Alanylglycine & - & + \\
\hline D-Serine & - & w \\
\hline L-Serine & - & w \\
\hline Inosine & - & + \\
\hline Uridine & - & w \\
\hline Thymidine & - & w \\
\hline DL- $\alpha$-Glycerolphosphate & - & w \\
\hline Glucose 1-phosphate & - & w \\
\hline Glucose 6-phosphate & - & W \\
\hline
\end{tabular}

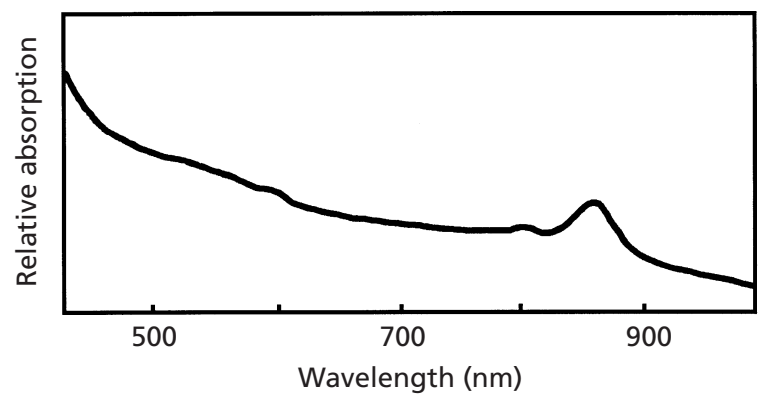

Fig. 3. In vivo absorption spectra of 8-month-old strain EL-38 ${ }^{\top}$ cells grown aerobically on PYGV $+25 \%$ ASW agar in the dark.

medium 3 or 4 (Table 1) autoxidation of Na-sulfite was visible after $18 \mathrm{~h}$, followed by a bromothymol blue indicator colour change from blue to yellow. Bacterial growth of Ekho Lake strains and Sulfitobacter pontiacus was indicated by (i) colony formation and (ii) blue zones around the colonies, which showed the $\mathrm{pH}$ to be $>6 \cdot 0$. Acetate and peptone assimilation could be reasons for this locally increased $\mathrm{pH}$. On agar media, all strains grew at initial sulfite concentrations up to $45 \mathrm{mM}$, but only Sulfitobacter pontiacus grew at $60 \mathrm{mM}$ sulfite.

\section{DNA base composition}

The base ratios of the isolates are shown in Table 2 . Those of Sulfitobacter pontiacus differed from the $\mathrm{mol} \% \mathrm{G}+\mathrm{C}$ of the other tw. EL isolates.

\section{Dot-blot hybridizations}

At $70 \%$ stringency, DNA probes from EL-38 ${ }^{\mathrm{T}}$, EL$162^{\mathrm{T}}$ and Sulfitobacter pontiacus DSM $10014^{\mathrm{T}}$ hybridized only with their own chromosomal DNA.

\section{DISCUSSION}

Sequencing of $16 \mathrm{~S}$ rRNA genes confirmed that the two Ekho Lake isolates were members of distinct taxa within the $\alpha-3$ subclass of the Proteobacteria. The combination of respiratory lipoquinone, fatty acid and polar lipid data also indicated that these strains belonged to this group of organisms (above the species rank) within the $\alpha$-subclass of the Proteobacteria (Labrenz et al., 1998). Comparative 16S rRNA gene sequencing showed that the two bacteria from Ekho Lake were specifically associated with the Sulfitobacter-Roseobacter cluster of organisms, but not with Ruegeria algicola (Lafay et al., 1995) or Roseobacter gallaeciensis (Ruiz-Ponte et al., 1998). It is evident from treeing analyses that the genus Roseobacter, as currently recognized, is interdispersed with several other taxa. This is also reflected in the inclusion of $R$. algicola in the genus Ruegeria by Uchino et al. (1998).

The chemotaxonomic data indicated that members of the genus Roseobacter (i.e. Roseobacter litoralis and 
Roseobacter denitrificans) had a distinctive polar lipid composition, in which both species had phosphatidylglycerol, diphosphatidylglycerol and an unidentified amino lipid as the major components. In contrast, strains EL-162 ${ }^{\mathrm{T}}, \mathrm{EL}-38^{\mathrm{T}}$ and Sulfitobacter pontiacus all synthesized phosphatidylglycerol, phosphatidylethanolamine and phosphatidylcholine, together with the same unidentified amino lipid. This polar lipid composition serves to distinguish these two groups from one another, and clearly shows that the isolates EL-162 ${ }^{\mathrm{T}}$ and EL-38 ${ }^{\mathrm{T}}$ do not belong to the genus Roseobacter.

Sequence divergence values of $2 \%$ for strain EL-162 and $3.5 \%$ for strain EL- $38^{\mathrm{T}}$ indicated that both strains were phylogenetically closely related to Sulfitobacter pontiacus. Morphologically, both antarctic strains were more similar to Sulfitobacter pontiacus than to Roseobacter strains: their cells multiplied by monopolar growth (a budding process) and formed rosettes (Table 2, Fig. 1). The ability to oxidize sulfite and thereby to increase growth characterizes Sulfitobacter pontiacus (Sorokin, 1995). Although EL-162 ${ }^{\mathrm{T}}$ and the type strain of Sulfitobacter pontiacus tolerated and grew in liquid media with initial sulfite concentrations of $20 \mathrm{mM}$, sulfite oxidation or a stimulation of growth could not be demonstrated with EL-162 ${ }^{\mathrm{T}}$ or EL-38 ${ }^{\mathrm{T}}$. The chemotaxonomic data indicated that the type strain of Sulfitobacter pontiacus and the two antarctic isolates were very similar. The polar lipids were qualitatively identical in Sulfitobacter pontiacus and strain EL-162 ${ }^{\mathrm{T}}$, but strain EL-38 ${ }^{\mathrm{T}}$ did not synthesize diphosphatidylglycerol, which was present in the other two organisms. Also, there were some differences in the fatty acid composition. In particular, strain EL$162^{\mathrm{T}}$ synthesized two isomers of $18: 2$ together with $18: 1 \omega 9 c$ and $18: 1 \omega 7 c$, whereas strain EL-38 ${ }^{\mathrm{T}}$ synthesized only one isomer of $18: 2$ and $18: 1 \omega 7 c$,

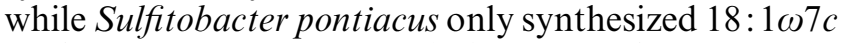
(Table 2). Examination of the $\mathrm{G}+\mathrm{C}$ base content indicated that the value for EL-38 ${ }^{\mathrm{T}}$ was about $5 \mathrm{~mol} \%$ lower than that for Sulfitobacter pontiacus, while the value for strain EL-162 ${ }^{\mathrm{T}}$ was about $3 \mathrm{~mol} \%$ lower. The significance of differences in the $\mathrm{G}+\mathrm{C}$ base content in an evolutionary context has been outlined by De Ley (1967).

The two EL-strains showed distinct differences in their metabolism of carbon compounds, as detected with the BIOLOG system (Table 3). Other differences concerned bchl $a$, which was present in light- or darkgrown cells of EL-38 ${ }^{\mathrm{T}}$, as shown by in vivo absorption bands at 800-802 and 861-862 nm (Yurkov \& Beatty, 1998). But these peaks were clearly absent from EL$162^{\mathrm{T}}$, from the Roseobacter spp. and Sulfitobacter pontiacus. The importance of bchl $a$ for taxonomic separation of these aerobic bacteria has already been questioned (Labrenz et al., 1999).

In conclusion, organisms of the SulfitobacterRoseobacter cluster appear to be phylogenetically quite closely related (Fig. 3), but phenotypically they are very diverse (Table 2). On the basis of the chemical data presented here we consider that the genus Roseobacter (containing only Roseobacter litoralis and Roseobacter denitrificans) is taxonomically distinct from Sulfitobacter pontiacus and the two strains EL-38 ${ }^{\mathrm{T}}$ and EL-162 ${ }^{\mathrm{T}}$. This is so despite the relatively 'high' degree of $16 \mathrm{~S}$ rDNA sequence similarity. That the genera Sulfitobacter and Roseobacter share a common ancestor is evident by the 16S rDNA sequence data and the similarities in chemotaxonomic data. However, it should be noted that the creation of taxa based solely on arbitarily determined sequence similarity levels (Fry et al., 1991; Devereux et al., 1990) does not take into account the phenotypic diversity of prokaryotes, which is also an indirect measure of their genotypic diversity. The potential stability in prokaryotic taxonomy is better served by using a wide range of 'reliable' markers, by which taxa are defined (a polythetic system), rather than using one dominant marker (a monothetic system), a problem which has been discussed previously (Tindall, 1994). Although the present data show that strains EL- $38^{\mathrm{T}}$ and EL-162 do not belong in the genus Roseobacter, there are three alternatives: (i) To unite the EL-strains with members of the genus Sulfitobacter. However, 16S rRNA gene sequence divergence between the two antarctic isolates was nearly $4 \%$, dot-blot hybridization was not observed at $70 \%$ stringency, and significant physiological and chemotaxonomic differences from Sulfitobacter pontiacus were found (Table 2). (ii) To split both Ekho Lake strains into two new genera. EL-162 ${ }^{\mathrm{T}}$ has a sequence divergence from Sulfitobacter pontiacus of only $2 \%$, its sulfite tolerance was fairly high, and physiological properties were quite similar to those of Sulfitobacter pontiacus. (iii) To create a new genus for EL-38 ${ }^{\mathrm{T}}$, and place strain EL-162 ${ }^{\mathrm{T}}$ in the genus Sulfitobacter as a new species. In our opinion, this last possibility would be suitable, because strain EL-38 ${ }^{\mathrm{T}}$ does not fulfil all criteria for inclusion in the genus Sulfitobacter. It could be placed intermediately between Roseobacter (Shiba, 1991) and Sulfitobacter (Sorokin, 1995), but as a representative of a new genus and species. We propose for it the name Staleya guttiformis gen. nov., sp. nov.

EL- $162^{\mathrm{T}}$ is phylogenetically more closely related to Sulfitobacter pontiacus. In addition, both of these bacteria had the same polar lipid pattern; they utilized butyrate and did not produce bchl $a$ (Table 2). Both organisms grew well in liquid media at initial sulfite concentrations of $20 \mathrm{mM}$. Based on these observations we consider strain EL-162 ${ }^{\mathrm{T}}$ to be a new species of the genus Sulfitobacter and propose the name Sulfitobacter brevis sp. nov.

\section{Description of Staleya gen. nov.}

Staleya (Sta'ley.a. M.L. n. Staleya after the American microbiologist J. T. Staley in recognition of his work on budding and appendaged bacteria and his contributions to polar microbiology).

Gram-negative rods with one or both cell poles 
pointed, multiplying by monopolar growth, i.e. by a budding process. Cells may be motile, may contain poly- $\beta$-hydroxybutyrate and do not form spores. On medium PYGV + ASW colonies are smooth, convex and beige to pink. Bchl $a$ may be produced. The temperature range for growth is from $<4$ to $32^{\circ} \mathrm{C}$. The cells have a weak requirement for $\mathrm{Na}^{+}$, growing in the range of $<1.0$ to $4.0 \% \mathrm{NaCl}$. In the presence of ASW they grow between $<10$ and $<150 \%$. The $\mathrm{pH}$ tolerance range is $5 \cdot 3-6 \cdot 5$ to $>9$. Strictly aerobic, nonfermentative heterotrophs. No growth on glucose anaerobically in the absence of nitrate. They do not grow photoautotrophically with $\mathrm{H}_{2} / \mathrm{CO}_{2}(80: 20)$ or photo-organotrophically with acetate or glutamate. The cells exhibit peroxidase, cytochrome oxidase and weak catalase activity. Polar lipids present are: phosphatidylglycerol, phosphatidylcholine, phosphatidylethanolamine, as well as an unknown aminolipid. Dominant fatty acid is $18: 1 \omega 7 c$; other characteristic fatty acids are $3-\mathrm{OH} 10: 0,3-\mathrm{OH} 14: 1,16: 0,18: 0$, $18: 2$ and 19:1. Major respiratory quinone is Q-10. Origin: water sample from Ekho Lake, Antarctica. The type species of the genus is Staleya guttiformis.

\section{Description of Staleya guttiformis sp. nov.}

Staleya guttiformis (gut.ti.for'mis. L. fem. n. gutta the drop; M.L. n. guttiformis drop-shaped).

Cell sizes vary from $1.0-1.5 \times 1.5-8.9 \mu \mathrm{m}$, with a mean of $1.1 \times 1.8 \mu \mathrm{m}$. On medium PYGV + ASW, colonies are smooth, convex and beige, later pink. Optimal growth occurs at $12-20{ }^{\circ} \mathrm{C}$ with $1.0 \% \mathrm{NaCl}$ or $10-40 \%$ ASW. The optimum pH is $7 \cdot 0-8 \cdot 5$. Bchl $a$ may be produced in older cells with a larger in vivo absorption band at 861-862 nm and small ones at 590-592 and 800-802. Production of bchl $a$ is not totally repressed by constant dim light. S. guttiformis has an absolute requirement for pantothenate and a weak one for thiamin, biotin and nicotinic acid. Tween 80 and DNA are hydrolysed, but not alginate, gelatin or starch. Growth occurs on acetate, pyruvate, malate, succinate or glutamate, but not on citrate, butyrate, methanesulfonic acid or methanol. $\alpha$-D-Glucose is only weakly utilized. Cells are susceptible to chloramphenicol, streptomycin, penicillin $\mathrm{G}$, tetracycline, polymyxin B or nalidixic acid. Nitrate is aerobically reduced to nitrite. $\mathrm{H}_{2} \mathrm{~S}$ and indole are not produced. Methyl redand Voges-Proskauer-negative. The $\mathrm{G}+\mathrm{C}$ content is $55 \cdot 0-56 \cdot 3 \mathrm{~mol} \%$. Chemotaxonomic properties and other characteristics are as described for the genus. The type strain of Staleya guttiformis $\left(\right.$ EL-38 $\left.{ }^{\mathrm{T}}\right)$ has been deposited in the Deutsche Sammlung von Mikroorganismen und Zellkulturen as DSM $11458^{\mathrm{T}}$.

\section{Description of Sulfitobacter brevis sp. nov.}

Sulfitobacter brevis (bre'vis. L. adj. brevis short, referring to the short cells).

Gram-negative short rods with one or both cell poles pointed, multiplying by monopolar growth, i.e. by a budding process. Cell sizes vary from $0.8-1.0 \times 1 \cdot 1-$
$1.5 \mu \mathrm{m}$, with a mean size of $0.9 \times 1.3 \mu \mathrm{m}$. Rosettes may be formed. Cells may be motile and contain poly- $\beta$-hydroxybutyrate; do not form spores. On PYGV + ASW the colonies are smooth, convex and yellowish-brown. The cells have an absolute requirement for $\mathrm{Na}^{+}$. Strictly aerobic, non-fermentative heterotrophs. Do not grow on glucose anaerobically in the absence of nitrate. Do not grow photoautotrophically with $\mathrm{H}_{2} / \mathrm{CO}_{2}(80: 20)$ or photo-organotrophically with acetate or glutamate. The cells exhibit peroxidase, catalase and cytochrome oxidase activity. Optimal growth occurs between 3 and $26{ }^{\circ} \mathrm{C}$ with $1 \cdot 0-2.0 \% \mathrm{NaCl}$ or $10-80 \%$ ASW. The optimum $\mathrm{pH}$ is $7 \cdot 5-8 \cdot 0$. Bchl $a$ is not produced. Cells have a requirement for pantothenate and thiamin, a weak requirement for biotin and nicotinic acid, but none for vitamin $\mathrm{B}_{12}$. Tween 80 is hydrolysed, but not alginate, gelatin, DNA or starch. Growth occurs on acetate, pyruvate, malate, succinate, citrate, butyrate or glutamate, but not on methanesulfonic acid or methanol. $\alpha$-D-Glucose is utilized weakly. Cells are susceptible to chloramphenicol, streptomycin, penicillin $\mathrm{G}$, polymyxin $\mathrm{B}$ and tetracycline, but not to nalidixic acid. Nitrate is not reduced, $\mathrm{H}_{2} \mathrm{~S}$ and indole are not produced. Methyl red- and Voges-Proskauer-negative. Polar lipids present are: diphosphatidylgycerol, phosphatidylglycerol, phosphatidylcholine, phosphatidylethanolamine and an unknown aminolipid. Dominant fatty acids are $18: 1 \omega 7 c$ and $18: 1 \omega 9 c$ and $18: 2$ is present as two isomers. Other characteristic fatty acids are 3-OH 10:0, 3-OH 14:1, 16:0 and 18:0. Major respiratory quinone is $\mathrm{Q}-10$. The $\mathrm{G}+\mathrm{C}$ content is $57.9-58 \cdot 1 \mathrm{~mol} \%$. Origin: water sample from Ekho Lake, Antarctica. The type strain of Sulfitobacter brevis $\left(\mathrm{EL}-162^{\mathrm{T}}\right)$ has been deposited in the Deutsche Sammlung von Mikroorganismen und Zellkulturen as DSM $11443^{\mathrm{T}}$.

\section{ACKNOWLEDGEMENTS}

We gratefully acknowledge skillful technical assistance of B. Hoffmann, M. Beese, G. Braker, R. Emcke and J. Buschdorf. J. Siebert (Hamburg) helped with the antarctic field work, and H. Völker (Kiel) with electron microscopy. Thanks are also due to J. Küver (Bremen) for helpful advice concerning sulfite oxidation. We especially want to thank the Australian Antarctic Division (Kingston, Tasmania) for supporting two summer visits to Davis Station (Antarctica). H. R. Burton (Australian Antarctic Division) and Professor T. A. McMeekin (University of Tasmania, Hobart) supported this research with much practical help and generous hospitality. We thank the Deutsche Forschungsgemeinschaft (DFG) for grants Hi 68/16-3, Hi 68/19-3 and Hi 68/25-1-3, and the European Union for grants CT 930194 and CT 93-0119.

\section{REFERENCES}

Bradford, M. M. (1976). A rapid and sensitive method for the quantitation of microgram quantities of protein utilizing the principle of protein-dye binding. Anal Biochem 72, 248-254.

Burton, H. R. (1981). Chemistry, physics and evolution of Antarctic saline lakes. A review. Hydrobiologia 82, 339-362. 
Cohen-Bazire, G., Sistrom, W. R. \& Stanier, R. Y. (1957). Kinetic studies of pigment synthesis by non-sulfur purple bacteria. $J$ Cell Physiol 49, 25-68.

De Ley, J. (1967). Molecular biology and bacterial phylogeny. In Evolutionary Biology, vol. 2, pp. 103-156. Edited by T. Dobzhansky, M. K. Hecht \& W. C. Steere. New York \& London: Plenum.

Devereux, J., Haeberli, P. \& Smithies, O. (1984). A comprehensive set of sequence analysis programs for the VAX. Nucleic Acids Res 12, 387-395.

Devereux, R., He, S.-H., Doyle, C. L., Orkland, S., Stahl, D. A., LeGall, J. \& Whitman, W. B. (1990). Diversity and origin of Desulfovibrio species: phylogenetic definition of a family. J Bacteriol 172, 3609-3619.

Drews, G. (1974). Mikrobiologisches Praktikum, 2. Auflage. Berlin: Springer.

van Ert, M. \& Staley, J. T. (1971). Gas-vacuolated strains of Microcyclus aquaticus. J Microbiol 108, 236-240.

Felsenstein, J. (1989). PHYLIP-phylogeny inference package (version 3.2). Cladistics 5, 164-166.

Fry, N. K., Warwick, S., Saunders, N. A. \& Embley, T. M. (1991). The use of $16 \mathrm{~S}$ rRNA analyses to investigate the phylogeny of the family Legionellaceae. J Gen Microbiol 137, 1215-1222.

Gonzalez, J. M., Mayer, F., Moran, M. A., Hodson, R. E. \& Whitman, W. B. (1997). Sagittula stellata gen. nov., sp. nov., a lignin-transforming bacterium from a coastal environment. Int J Syst Bacteriol 47, 773-780.

Gosink, J. J., Herwig, R. P. \& Staley, J. T. (1997). Octadecabacter arcticus gen. nov., sp. nov., and $O$. antarcticus sp. nov., nonpigmented, psychrophilic gas vacuolate bacteria from polar sea ice and water. Syst Appl Microbiol 20, 356-365.

Groth, I., Schumann, P., Weiss, N., Martin, K. \& Rainey, F. A. (1996). Agrococcus jenensis gen. nov., sp. nov., a new genus of actinomycetes with diaminobutyric acid in the cell wall. Int $J$ Syst Bacteriol 46, 234-239.

Harashima, K., Nakagawa, M. \& Murata, N. (1982). Photochemical activities of bacteriochlorophyll in aerobically grown cells of aerobic heterotrophs, Erythrobacter species (OCh 114) and Erythrobacter longus (OCh 101). Plant Cell Physiol 23, 185-193.

Holmes, A. J., Kelly, D. P., Baker, S. C., Thompson, A. S., De Marco, P., Kenna, E. M. \& Murrell, J. C. (1997). Methylosulfonomonas methylovora gen. nov., sp. nov., and Marinosulfonomonas methylotropha gen. nov., sp. nov.: novel methylotrophs able to grow on methanesulfonic acid. Arch Microbiol 167, 46-53.

Hudson, R. A., Thompson, D. E. \& Collins, M. D. (1993). Genetic interrelationships of saccharolytic Clostridium botulinum types $\mathrm{B}, \mathrm{E}$ and $\mathrm{F}$ and related clostridia by small-subunit rRNA gene sequences. FEMS Microbiol Lett 108, 103-110.

James, S. R. (1996). Ecology of bacteria from antarctic hypersaline lakes. PhD thesis, University of Tasmania.

Jukes, T. H. \& Cantor, C. R. (1969). Evolution of protein molecules. In Mammalian Protein Metabolism, pp. 21-132. Edited by H. N. Munro. New York: Academic Press.

Kreisel, H., \& Schauer, F. (1987). Methoden des mykologischen Laboratoriums. Stuttgart: Gustav Fischer.

Labrenz, M., Collins, M. D., Lawson, P. A., Tindall, B. J., Braker, G. \& Hirsch, P. (1998). Antarctobacter heliothermus gen. nov., sp. nov., a budding bacterium from hypersaline and heliothermal Ekho Lake. Int J Syst Bacteriol 48, 1363-1372.
Labrenz, M., Collins, M. D., Lawson, P. A., Tindall, B. J., Schumann, P. \& Hirsch, P. (1999). Roseovarius tolerans gen. nov., sp. nov., a budding bacterium with variable bacteriochlorophyll $a$ production from hypersaline Ekho Lake. Int J Syst Bacteriol 49, 137-147.

Lafay, B., Ruimy, R., Rausch de Traubenberg, C., Breittmayer, V., Gauthier, M. J. \& Christen, R. (1995). Roseobacter algicola sp. nov., a new marine bacterium isolated from the phycosphere of the toxin-producing dinoflagellate Prorocentrum lima. Int J Syst Bacteriol 45, 290-296.

Lyman, J., \& Fleming, R. H. (1940). Composition of sea water. $J$ Mar Res (Sears Found) 3, 134-146.

Mesbah, M., Premachandran, U. \& Whitman, W. B. (1989). Precise measurement of the $\mathrm{G}+\mathrm{C}$ content of deoxyribonucleic acid by high-performance liquid chromatography. Int $J$ Syst Bacteriol 39, 159-167.

Pearson, W. R. \& Lipman, D. J. (1988). Improved tools for biological sequence comparison. Proc Natl Acad Sci USA 85, 2444-2448.

Pfennig, N. \& Wagener, S. (1986). An improved method of preparing wet mounds for photographs of microorganisms. J Microbiol Methods 4, 303-306.

Rhuland, L. E., Work, E., Denman, R. F. \& Hoare, D. S. (1955). The behavior of the isomers of $\alpha, \varepsilon$-diaminopimelic acid on paper chromatogramms. J Am Chem Soc 77, 4844-4846.

Ruiz-Ponte, C., Cilia, V., Lambert, C. \& Nicolas, J. L. (1998). Roseobacter gallaeciensis sp. nov., a new marine bacterium isolated from rearings and collectors of the scallop Pecten maximus. Int J Syst Bacteriol 48, 537-542.

Saitou, N. \& Nei, M. (1987). The neigbor-joining method: a new method for reconstructing phylogenetic trees. Mol Biol Evol 4, 406-425.

Sambrook, J., Fritsch, E. F. \& Maniatis, T. (1989). Molecular Cloning: a Laboratory Manual, 2nd edn. Cold Spring Harbor, NY : Cold Spring Harbor Laboratory.

Shiba, T. (1991). Roseobacter litoralis gen. nov., sp. nov., and Roseobacter denitrificans sp. nov., aerobic pink-pigmented bacteria which contain bacteriochlorophyll a. Syst Appl Microbiol 14, 140-145.

Shiba, T. \& Simidu, U. (1982). Erythrobacter longus gen. nov., sp. nov., an aerobic bacterium which contains bacteriochlorophyll a. Int J Syst Bacteriol 32, 211-217.

Skerman, V. B. D. (1967). A Guide to the Identification of the Genera of Bacteria, 2nd edn. Baltimore: Williams \& Wilkins.

Smibert, R. M. \& Krieg, N. R. (1994). Phenotypic characterization. In Methods for General and Molecular Bacteriology, pp. 607-654. Edited by P. Gerhardt, R. G. E. Murray, W. A. Wood \& N. R. Krieg. Washington, DC: American Society for Microbiology.

Sorokin, D. Y. (1995). Sulfitobacter pontiacus gen. nov., sp. nov. - a new heterotrophic bacterium from the Black Sea, specialized on sulfite oxidation. Mikrobiologiya 64, 354-365 (English translation, 295-305).

Sorokin, D. Yu. \& Lysenko, A. M. (1993). Heterotrophic bacteria from the Black Sea oxidizing reduced sulfur compounds to sulfate. Mikrobiologiya 62, 1018-1031 (English translation, 594-602).

Staley, J. T. (1968). Prosthecomicrobium and Ancalomicrobium, new prosthecate fresh water bacteria. J Bacteriol 95, 1921-1944.

Tindall, B. J. (1990a). A comparative study of the lipid composition of Halobacterium saccharovorum from various sources. Syst Appl Microbiol 13, 128-130. 
Tindall, B. J. (1990b). Lipid composition of Halobacterium lacusprofundi. FEMS Microbiol Lett 66, 199-202.

Tindall, B. J. (1994). Chemical analysis of Archaea and Bacteria: A critical evaluation of its use in taxonomy and identification. In Bacterial Diversity and Systematics (FEMS Symposium no. 75), pp. 243-258. Edited by F. G. Priest, A. RamosCormenzana \& B. J. Tindall. New York: Plenum.

Uchino, Y., Hirata, A., Yokota, A. \& Sugiyama, J. (1998).
Reclassification of marine Agrobacterium species: proposals of Stappia stellulata gen. nov., comb. nov., Stappia aggregata sp. nov., nom. rev., Ruegeria atlantica gen. nov., comb. nov., Ruegeria gelatinovora comb. nov., Ruegeria algicola comb. nov., and Ahrensia kieliense gen. nov., sp. nov., nom. rev. J Gen Appl Microbiol 44, 201-210.

Yurkov, V. V. \& Beatty, J. T. (1998). Aerobic anoxygenic phototrophic bacteria. Microbiol Mol Biol Rev 62, 695-724. 